\title{
AKSELERASI:
}

JURNAL PENDIDIKAN GURU MI

Volume 1, Nomor 2, Desember 2020, Hal. 81-93

\section{ANALISIS MEDIA PEMBELAJARAN BERBASIS E-LEARNING DI MASA PANDEMI COVID-19 PADA GURU SD/MI DI JEMBER}

\author{
Siti Latifah ${ }^{1}$, Nuril Azrina ${ }^{2}$ \\ ${ }^{1}$ Tadris Biologi, FTIK, IAIN Jember, Jl. Mataram No. 1 Mangli, Jember 68136, Jawa Timur, Indonesia \\ e-mail: efafieda@gmail.com \\ ${ }^{2}$ IAIN Jember, Jl. Mataram No.1 Mangli Jember, Jawa Timur Indonesia \\ e-mail: nurilazrina13@gmail.com
}

\begin{abstract}
This study aims to analyze e-learning-based learning media during the COVID-19 pandemic used by SD / MI teachers in Jember and the factors that support and hinder the elearning based learning media. The method used in this research is descriptive qualitative method. Respondents in this study were SD / MI teachers in Jember. The data was collected by distributing questionnaires and online interviews. The results showed that during the COVID-19 pandemic, SD / MI teachers in Jember conducted e-learning based learning. The e-learning-based learning media that is most widely used is Whatsapp as the main media for e-learning based learning. Then as supporting media, SD / MI teachers also use Google Classroom, Edmoodo, Zoom, Quizizz, and other e-learning based learning media. In using e-learning based learning media, the biggest obstacle is the internet quota, then there are other inhibiting factors such as internet network access, facilities / infrastructure, time, skills in using learning media. While the factors that support SD / MI teachers in using e-learning-based learning media are e-learning features, facilities / infrastructure, internet quotas, skills in using learning media.
\end{abstract}

Keywords: e-learning, learning media, COVID-19, teachers.

\begin{abstract}
ABSTRAK
Penelitian ini bertujuan untuk menganalisis media pembelajaran berbasis e-learning di masa pandemi COVID-19 yang digunakan oleh guru SD/MI di Jember dan faktor yang mendukung seta menghambat media pembelajaran berbasis e-learning tersebut. Metode yang digunakan dalam penelitian ini menggunakan metode deskriptif kualitatif. Responden dalam penelitian ini adalah guru SD/MI di Jember.Pengumpulan data dilakukan dengan menyebarkan kuesioner dan wawancara secara online. Hasil penelitian menunjukkan bahwa saat pandemi COVID-19 membuat guru SD/MI di Jember melakukan pembelajaran berbasis e-learning. Media pembelajaran berbasis e-learning yang paling banyak digunakan adalah Whatsapp sebagai media utama pembelajaran berbasis e-learning. Kemudian sebagai media pendukungnya guru SD/MI juga menggunakan Google Classroom, Edmoodo, Zoom, Quizizz, dan media pembelajaran berbasis e-learning lainnya. Dalam menggunakan media pembelajaran berbasis e-learning yang menjadi hambatan paling besar adalah kuota internet, kemudian juga terdapat faktor penghambat yang lain seperti akses jaringan internet, fasilitas/sarana prasarana, waktu, skill menggunakan media pembelajaran. Sedangkan faktor yang mendukung guru SD/MI dalam menggunakan media
\end{abstract}


pembelajaran berbasis e-learning yaitu fitur-fitur e-learning, fasilitas/sarana prasarana, kuota internet, skill menggunakan media pembelajaran.

Kata Kunci: e-learning, media pembelajaran, COVID-19, guru.

\section{PENDAHULUAN}

Media pembelajaran merupakan semua alat bantu yang digunakan oleh guru untuk membantu suatu proses pembelajaran sehingga materi, pesan, ataupun informasi yang diberikan oleh guru maupun sumber lain dapat tersampaikan kepada peserta didik dengan lebih mudah dan membuat peserta didik lebih aktif dan termotivasi (Sadiman, 2008). Dalam pembelajaran pasti melibatkan media pembelajaran sebagai alat bantu agar guru dan peserta didik dapat mencapai tujuan pendidikan. Pembelajaran merupakan semua interaksi yang telah dirancang guna mendukung proses belajar peserta didik untuk mengaktifkan, mendukung, dan mempertahankan proses pembelajaran yang terjadi. (Winkel, 2010) mengemukakan bahwa "pembelajaran adalah semua tindakan yang telah disusun guna mendukung proses belajar peserta didik, dengan mempertimbangkan peristiwa-peristiwa ekstrim yang berperan dalam rangkaian peristiwa-peristiwa yang terjadi dan dialami peserta didik". Media pembelajaran memberikan manfaat terhadap keberlangsungan pembelajaran, manfaat dari pemakaian media pembelajaran yaitu dengan adanya media pembelajaran penyajian materi dari guru lebih jelas dan tidak terlalu verbalistis, keterbatasan ruang, waktu, dan indera dapat teratasi. Digunakannya media pembelajaran dapat membuat peserta didik lebih aktif, dan masing-masing peserta didik yang memiliki latar belakang yang berbeda mendapatkan informasi yang sama dari guru.

Media pembelajaran tidak hanya sebagai alat bantu pembelajaran saja, akan tetapi juga sebagai sumber belajar untuk terciptanya suasana belajar yang efektif dan efisien sehingga media pembelajaran ini harus dimanfaatkan secara maksimal (Dewi, 2018). Dalam hal ini guru memiliki peran yang penting dalam menciptakan inovasi baru terhadap media pembelajaran yang akan dipakainya saat pembelajaran dengan peserta didik. Guru merupakan seseorang yang secara langsung berhadapan dengan peserta didik di tempat belajar (kelas) dalam kegiatan belajar mengajar, yang tugasnya untuk menciptakan SDM berkualitas yang dapat bersaing sampai tingkat internasional. Keberhasilan peserta didik dalam mencapai tujuan pendidikannya ada di tangan guru. Peran guru dalam kegiatan pembelajaran sangatlah penting untuk mencetak peserta didik yang berkualitas baik dalam akademis, emosional, spiritual serta moralnya (Putri et al., 2020). Untuk menunjang keberlangsungan kegiatan pembelajaran dapat berjalan dengan baik, sesorang guru memerlukan media pembelajaran yang tepat dalam menyampaikan materi atau pesannya agar lebih mudah diterima oleh peserta didik.

Sampai saat ini Indonesia digemparkan dengan adanya wabah COVID-19 (Corona Virus Disease), tidak hanya di Indonesia saja bahkan wabah COVID-19 ini juga sudah melanda \pm 200 
negara yang ada di dunia. Maraknya wabah COVID-19 ini menjadi tantangan tersendiri bagi negara-negara terdampak, salah satunya Indonesia. Di Indonesia sendiri dampak dari wabah COVID-19 tidak hanya dalam sektor ekonomi saja, akan tetapi sudah menjalar sampai ke dunia pendidikan. Untuk memutus rantai penyebaran COVID-19 pemerintah pusat telah memberikan kebijakan terhadap seluruh pendidikan di Indonesia, yakni dengan memberlakukan aturan "stay at home" dan meliburkan seluruh kegiatan pembelajaran tatap muka secara langsung. Hal seperti itu tidak hanya diterapkan di Indonesia saja, Negara-negara terdampak seperti Amerika, Spanyol, dan Negara terdampak lainnya juga telah memberlakukan aturan "stay at home" dan meliburkan seluruh kegiatan pembelajaran di sekolah (Anhusadar, 2020).

Namun, kebijakan pemerintah ini tidak menyurutkan semangat guru untuk terus berinovasi agar kegiatan belajar mengajar yang dilakukannya dapat berjalan dengan baik guna mencapai tujuan pendidikan yang diinginkan. Agar pendidikan di Indonesia terus berjalan pemerintah menetapkan bahwa pembelajaran tatap muka secara langsung diubah menjadi pembelajaran jarak jauh, misalnya seperti pembelajaran berbasis e-learning. Pembelajaran berbasis e-learning adalah kegiatan belajar antara guru dan peserta didik baik formal maupun informal yang dilakukan dengan menggunakan teknologi informasi atau alat elektronik, seperti komputer, handphone, internet dan semacamnya (Simanihuruk. et al, 2019). Dalam situasi pandemi seperti saat ini, guru dituntut untuk menciptakan suasana belajar yang kondusif agar peserta didik dapat terlibat sepenuhnya pada kegiatan pembelajaran. Hal ini tentunya bergantung pada media pembelajaran berbasis e-learning yang digunakan oleh guru sebagai pendidik. Karena disini guru memiliki peran yang sangat strategis sebab keberadaannya sangat berkaitan dengan keberhasilan dan kualitas pendidikan (Fauzi, 2018). Namun dengan dialihkannya pembelajaran tatap muka secara langsung menjadi pembelajaran berbasis e-learning banyak problematika yang dihadapi oleh guru. Misalnya seperti banyaknya keluhan dari orang tua peserta didik mengenai tugas-tugas yang diberikan oleh guru kepada anak-anak mereka dan keluhan orang tua peserta didik tentang fasilitas pembelajaran yang kurang mendukung. Akan tetapi pembelajaran berbasis e-learning ini ternyata juga memiliki beberapa kelebihan. Adapun salah satu kelebihan dari e-learning yaitu guru dapat mengajar dan menyampaikan materi tanpa hadir dalam ruang kelas begitupun juga dengan peserta didik, sehingga pembelajaran dapat lebih efektif dan hemat biaya karena dapat dilakukan kapanpun dan dimanapun sesuai dengan situasi dan kondisi guru dan peserta didik (Simanihuruk. et al, 2019).

Di samping pembelajaran berbasis e-learning memiliki kelebihan-kelebihan sebagaimana yang telah disebutkan di atas, pembelajaran berbasis e-learning juga memiliki kekurangan. Adapun kekurangan dari pembelajaran berbasis e-learning yaitu diperlukan adanya alat teknologi informasi seperti komputer, monitor, keyboard sebagai peralatan tambahan untuk menunjang proses pembelajaran. Minimnya interaksi secara tatap muka langsung antara guru dan peserta didik, adanya permasalahan listrik, telepon dan komputer karena kurang meratanya ketersediaan fasilitas 
internet. Peserta didik menjadi frustasi karena peralatan yang digunakan dalam pembelajaran kurang mendukung seperti kurangnya jaringan internet, sehingga mereka kesulitan untuk mengakses gambar, grafik dan video. Berdasarkan permasalahan yang telah diuraikan tersebut di atas, maka penelitian ini bertujuan untuk menganalisis media pembelajaran yang digunakan oleh guru SD di kabupaten Jember selama pembelajaran jarak jauh di masa pandemi COVID-19 ini.

\section{METODE}

Penelitian ini dilakukan sejak 26 Oktober-30 Oktober 2020. Tujuan dari penelitian ini yaitu untuk menganalisis media pembelajaran berbasis e-learning yang digunakan di masa pandemi COVID-19 ini dan faktor yang mendukung dan menghambat media pembelajaran tersebut. Kita tahu bahwa pada pembelajaran berbasis e-learning ini ada banyak macam media pembelajaran yang digunakan. Maka diperlukan adanya analisis mengenai media pembelajaran tersebut dan faktor apa saja yang mendukung dan menghambat media pembelajaran berbasis e-learning tersebut.

Metode yang digunakan dalam penelitian ini yaitu metode deskriptif kualitatif. Metode deskriptif kualitatif merupakan prosedur penelitian yang hasilnya adalah data-data deskriptif berupa tulisan kata-kata atau ucapan atau berupa tindakan kebijakan (Subandi, 2011). Dalam penelitian ini menggunakan responden guru SD atau MI yang tersebar di kabupaten Jember yang sedang melakukan pembelajaran berbasis e-learning selama masa pandemi COVID-19. Dalam penelitian ini menggunakan 21 responden. Penelitian ini dilakukan dengan menyebarkan angket atau kuisioner secara online melalui google form kepada guru SD atau MI yang dijadikan sebagai responden dan menggunakan sumber-sumber terpercaya seperti jurnal, e-book atau buku, dan web yang berhubungan dengan penelitian ini. Angket atau kuisioner merupakan pertanyaan yang telah dibuat secara terdaftar yang kemudian diberikan kepada responden untuk menjawab pertanyaan yang jawabannya sudah disediakan untuk dipilih atau hanya disediakan kolom jawaban dari pertanyaan. Jenis angket yang digunakan adalah jenis angket tertutup, sama seperti kuisioner ganda, yaitu responden sudah bisa langsung memilih jawaban yang telah disediakan.

\section{HASIL DAN PEMBAHASAN}

Hasil penelitian ini didapatkan dari hasil penyebaran kuesioner secara online melalui Google Form dan wawancara secara online melalui Whathsapp. Berikut adalah hasil penelitian yang diperoleh dari penyebaran kuesioner melalui Google Form kepada guru SD/MI di Jember sebagai berikut: 


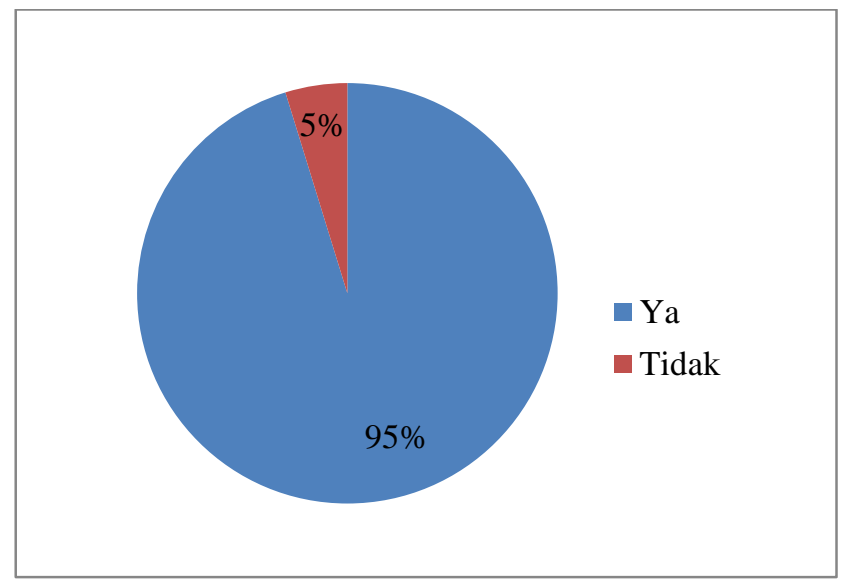

\section{Gambar 1. Persentase Pembelajaran Menggunakan E-learning}

Dari diagram lingkaran di atas menunjukkan selama masa pandemi COVID-19 pembelajaran pada anak Sekolah Dasar dilakukan secara e-learning. Hal tersebut dapat dilihat dari diagram lingkaran di atas, 95\% guru SD/MI di Jember menerapkan pembelajaran berbasis e-learning dan 5\% guru SD/MI di Jember tidak menerapkan pembelajaran berbasis $e$-learning.

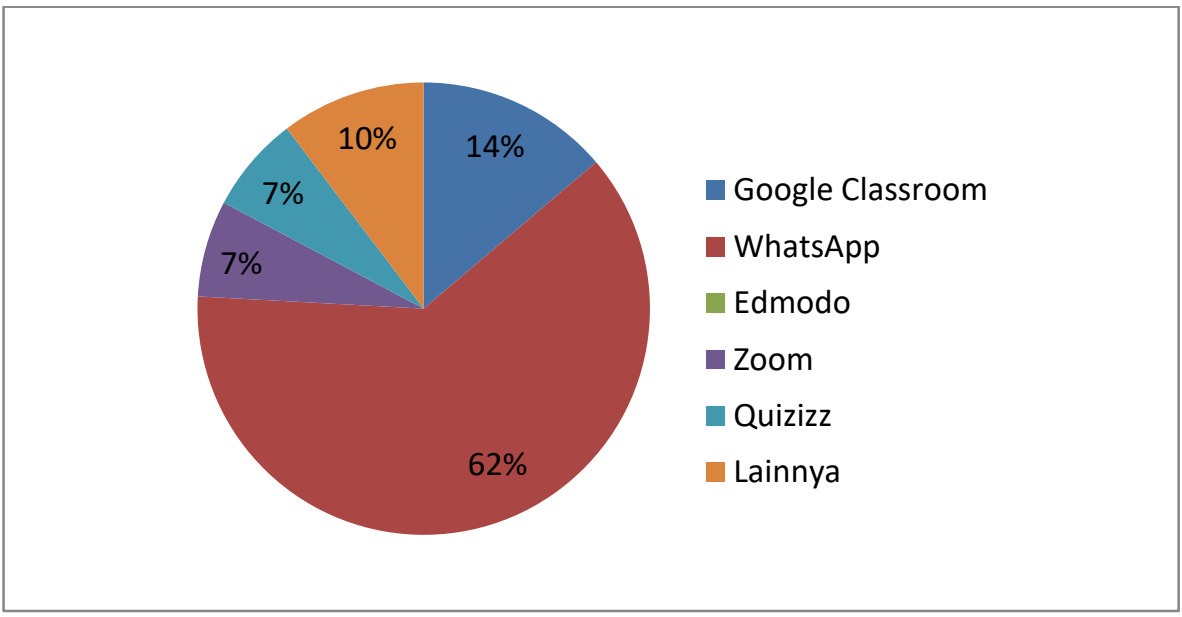

\section{Gambar 2. Media Pembelajaran Berbasis E-learning yang Digunakan Guru SD/MI}

Dari diagram lingkaran di atas menunjukkan macam-macam media pembelajaran yang digunakan oleh guru SD/MI selama pembelajaran berbasis e-learning di masa pandemi COVID-19. Dari diagram tersebut didapatkan bahwa 62\% guru SD/MI menggunakan Whatsapp sebagai media pembelajaran berbasis e-learning, 14\% guru SD/MI menggunakan Google Classroom sebagai media pembelajaran berbasis e-learning, 7\% guru SD/MI menggunakan Zoom sebagai media pembelajaran berbasis e-learning, 7\% guru SD/MI mengguanakan Quizizz sebagai media pembelajaran berbasis e-learning, 0\% guru SD/MI menggunakan Edmoodo sebagai media pembelajaran berbasis e-learning, dan 10\% guru SD/MI menggunakan media pembelajaran lainnya (seperti Google Form, Youtube, dan lain-lain) sebagai media pembelajaran berbasis e-learning. 


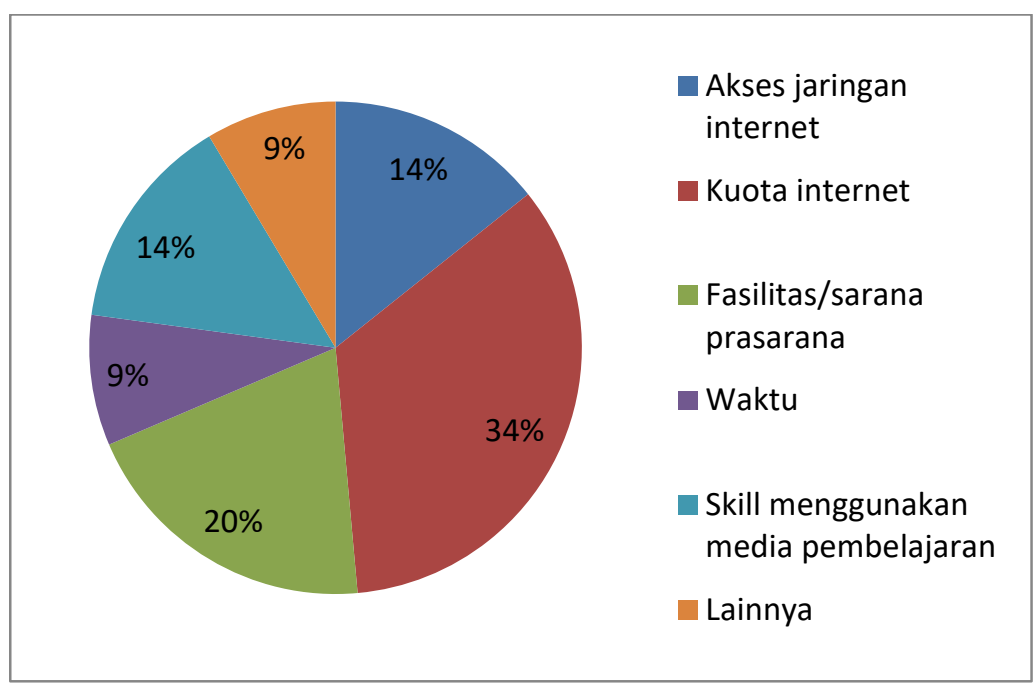

Gambar 3. Faktor Penghambat Media Pembelajaran Berbasis E-learning

Dari diagram lingkaran di atas menunjukkan faktor yang menghambat media pembelajaran yang digunakan oleh guru SD/MI selama pembelajaran berbasis e-learning di masa pandemi COVID-19. Dari diagram tersebut didapatkan bahwa 34\% kuota internet menjadi penghambat bagi guru SD/MI dalam menggunakanmedia pembelajaran berbasis e-learning, 20\% fasilitas atau sarana prasarana menjadi penghambat bagi guru SD/MI dalam menggunakan media pembelajaran berbasis e-learning, $14 \%$ akses jaringan internet menjadi penghambat bagi guru SD/MI dalam menggunakanmedia pembelajaran berbasis e-learning, $14 \%$ skill menggunakan media pembelajaran menjadi penghambat bagi guru SD/MI dalam menggunakan media pembelajaran berbasis e-learnig, 9\% waktu menjadi penghambat bagi guru SD/MI dalam menggunakan media pembelajaran berbasis e-learning, dan 9\% terdapat faktor lain yang menjadi penghambat bagi guru $\mathrm{SD} / \mathrm{MI}$ dalam menggunakan media pembelajaran berbasis e-learning (seperti biaya, Dan lain-lain).

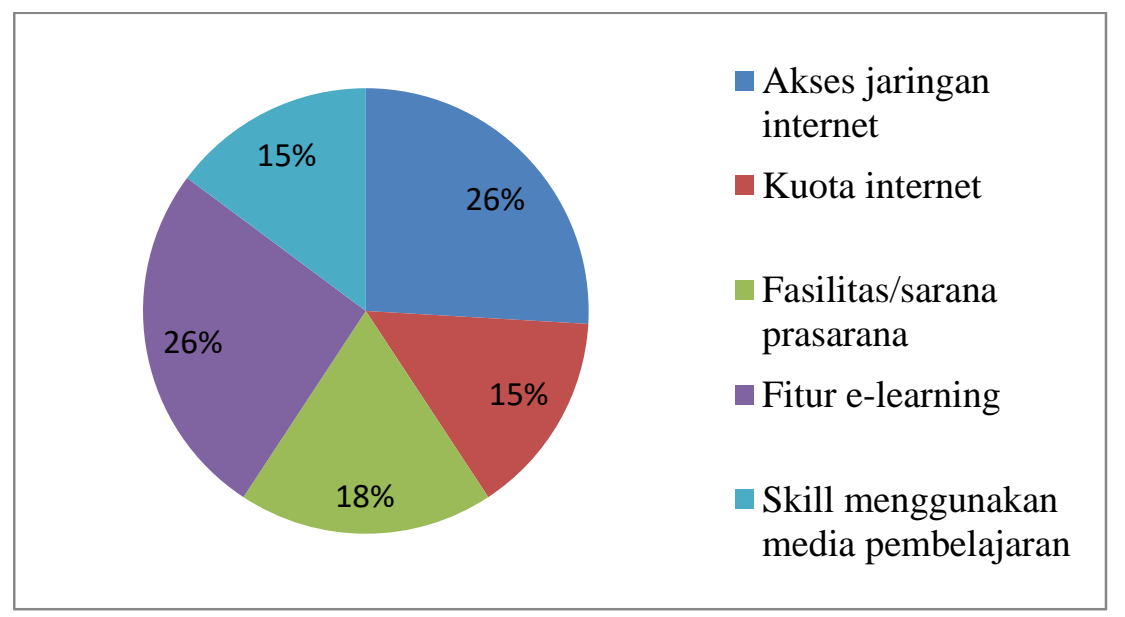

\section{Gambar 4. Faktor Pendukung Media Pembeajaran Berbasis E-learning}

Dari diagram lingkaran di atas menunjukkan faktor yang mendukung media pembelajaran yang digunakan oleh guru SD/MI selama pembelajaran berbasis e-learning di masa pandemi COVID-19. Dari diagram tersebut didapatkan bahwa 26\% akses jaringan internet menjadi 
pendukung bagi guru SD/MI dalam menggunakan media pembelajaran berbasis e-learning, 26\% fitur e-learning menjadi pendukung bagi guru SD/MI dalam menggunakan media pembelajaran berbasis e-learning, $18 \%$ fasilitas/sarana prasarana menjadi pendukung bagi guru SD/MI dalam menggunakan media pembelajaran berbasis e-learning, $15 \%$ skill menggunakan media pembelajaran menjadi pendukung bagi guru SD/MI dalam menggunakan media pembelajaran berbasis e-learning, $15 \%$ kuota internet menjadi pendukung bagi guru $\mathrm{SD} / \mathrm{MI}$ dalam menggunakan media pembelajaran berbasis e-learning.

Adapun hasil penelitian yang diperoleh dari wawancara melalui Whatsapp kepada dua guru SD/MI di Jember, yaitu Bu Arum (Guru MI Miftahul Ulum 02 Pondok Labu) dan Bu Rizki (Guru SDN Jenggawah 4) didapatkan hasil bahwa selama masa pandemi COVID-19 pembelajaran di sekolah dasar dilakukan secara e-learning karena hal tersebut sudah menjadi ketetapan dari pihak sekolah. Selama pembelajaran berbasis e-learning ini media pembelajaran berbasis e-learning yang paling banyak digunakan yaitu Whatsapp sebagai media utama dalam pembelajaran berbasis elearning di masa pandemi COVID-19, dikarenakan sebagian besar siswa telah mempunyai Whatsapp, sehingga pembelajaran dapat tetap berlangsung. Kemudian media pembelajaran berbasis e-learning lain yang digunakan sebagai pendukung Whatsapp yaitu Quizizz dan Google Form.

Kemudian, selama menggunakan media pembelajaran berbasis e-learning ini, kuota internet dan fasilitas atau sarana dan prasarana menjadi faktor yang menghambat guru dalam mengaplikasikan media pembelajaran berbasis e-learning. Hal tersebut dikarenakan terbatasnya kuota internet yang dimiliki guru karena tidak mendapatkan bantuan kuota internet, dan kurangnya fasilitas atau sarana dan prasarana yang dimiliki oleh guru maupun siswa sebagai penunjang pembelajaran selama masa pandemi COVID-19 ini. Di samping itu, ada juga faktor yang mendukung media pembelajaran berbasis e-learning selama pandemi COVID-19, yaitu skill dalam menggunakan media pembelajaran berbasis e-learning dan juga akses jaringan internet, karena untuk keberlangsungan pembelajaran berbasis e-learning ini membutuhkan jaringan internet untuk mendukung proses pembelajaran dan juga skill yang bagus untuk dapat memberikan inovasi baru selama pembelajaran e-learning di masa pandemi COVID-19 ini.

Dalam masa pandemi COVID-19 media pembelajaran berbasis e-learning menjadi alternatif paling tepat oleh guru agar proses pembelajaran dapat terus berjalan. Media pembelajaran berbasis e-learning yang digunakan oleh guru selama masa pandemi COVID-19 sangat menentukan berhasil dan tidaknya proses belajar mengajar dalam mencapai tujuan pendidikan. Media pembelajaran merupakan semua alat bantu yang digunakan oleh guru untuk membantu suatu proses pembelajaran sehingga materi, pesan, ataupun informasi yang diberikan oleh guru maupun sumber lain dapat tersampaikan kepada peserta didik dengan lebih mudah dan membuat peserta didik lebih aktif dan termotivasi (Sadiman, 2008). 
Berdasarkan dari hasil kuesioner dan wawancara yang dilakukan secara online kepada 21 guru SD/MI di Jember, pada hasil penelitian (Gambar 1) sebanyak 95\% guru SD/MI di Jember menggunakan pembelajaran berbasis e-learning dan 5\% tidak menerapkan pembelajaran berbasis e-learning di masa pandemi COVID-19 saat ini. 95\% dari 21 responden guru SD/MI menerapkan pembelajaran berbasis e-learning, ini dikarenakan di situasi pandemi COVID-19 pembelajaran berbasis e-learning merupakan cara paling efisien yang digunakan agar dapat memutus rantai penyebaran virus corona dan proses pembelajaran tetap berlangsung sesuai dengan surat edaran yang dikeluarkan oleh Kemendikbud Nomor 36962/MPK.A/HK/2020 pada tanggal 20 Maret 2020 yang menyatakan bahwa pembelajaran dan bekerja dilakukan secara daring dari rumah guna mencegah penyebaran COVID-19. Hal ini juga sesuai dengan penelitian yang dilakukan oleh Anugrahana (2020) bahwa guru melakukan pembelajaran daring supaya dapat mencegah penularan wabah COVID-19, selain itu pembelajaran daring dianggap paling efisien untuk mencegah terjadinya kerumunan dan angka penyebaran virus corona. Selain itu juga disebutkan bahwa alas an guru melakukan pembelajaran secara daring dikarenakan sebuah tanggungjawab guru sebagai pendidik untuk melakukan proses belajar mengajar meskipun dilakukan secara online. Sedangkan 5\% guru SD/MI tidak menerapkan pembelajaran berbasis e-learning dikarenakan pembelajaran berbasis e-learning dianggap tidak efektif dengan alasan materi tidak bisa tersampaikan dengan baik kepada siswa dan banyaknya hambatan dalam menerapkan pembelajaran berbasis e-learning.

Berdasarkan dari hasil kuesioner dan wawancara yang dilakukan secara online kepada 21 guru SD/MI di Jember, pada hasil penelitian (Gambar 2) yang menjadi aplikasi utama adalah WhatsApp. Serta Google Classroom, Zoom, Quizizz, Edmoodo dan aplikasi lainnya menjadi aplikasi pendukung Whatsapp. Sebanyak 62\% Guru SD/MI banyak yang memilih menggunakan Whatsapp sebagai media pembelajaran berbasis e-learning dikarenakan sebagian besar siswa sudah mempunyai Whatsapp, dan semua siswa tahu cara mengoperasikannya, serta Whatsapp relatif lebih murah jika dibandingkan dengan aplikasi yang lain. Jadi agar mereka bisa aktif mengikuti pembelajaran sehingga pembelajaran menjadi efektif. Whatsapp memudahkan guru menyampaikan pesan dalam bentuk tulisan, foto, voice note, dan video, disamping itu untuk mengakses Whatsapp guru dan siswa tidak membutuhkan kuota internet yang besar sehingga lebih mudah untuk menjangkau. Oleh karena itu Whatsapp merupakan media pembelajaran yang efektif dibandingkan dengan media yang lain karena dapat meningkatkan motivasi, keingintahuan dan digunakan sebagai sumber belajar mandiri (Maulah. et al, 2020). Kemudian 14\% guru SD/MI menggunakan Google Classroom dikarenakan fitur-fitur yang tersedia mudah dipahami oleh guru sehingga memudahkan guru dalam menyampaikan materi pembelajaran. Google Classroom juga dapat secara otomatis membuat salinan dari tugas-tugas yang sudah dikumpulkan oleh siswa sehingga memudahkan bagi guru dalam melakukan pengoreksian terhadap tugas yang telah dikumpulkan oleh masing-masing siswanya. Selanjutnya, Sebanyak 7\% guru SD/MI di Jember menggunakan 
Zoom sebagai media pembelajaran berbasis e-learning selama masa pandemi COVID-19, Zoom ini merupakan salah satu media pembelajaran pendukung Whatsapp agar siswa tidak merasakan jenuh dalam belajar. Menurut Astini, (2020) dalam penelitian menyebutkan bahwa dengan menggunakan Zoom guru dapat berkomunikasi dengan siswa lewat tatap muka secara online karena Zoom merupakan aplikasi komunikasi lewat video, yang memungkinkan untuk berbagi layar hingga sebanyak 100 orang dan merupakan aplikasi meeting HD gratis. Sebanyak 7\% guru SD/MI di Jember juga menggunakan Quizizz sebagai media pembelajaran berbasis e-learning sebagai media pendukung Whatsapp. Sebanyak 0\% guru SD/MI di Jember menggunakan Edmodoo sebagai media pembelajaran berbasis e-learning selama masa pandemi COVID-19, akan tetapi biasanya Edmoodo lebih digunakan dikalangan SD ke atas seperti SMP, SMA, dan Universitas. Terakhir $10 \%$ guru SD/MI menggunakan media pembelajaran lainnya (seperti Google Form, Youtube, dll) sebagai media pembelajaran berbasis e-learning di masa pandemi COVID-19. Youtube adalah salah satu media pembelajaran yang mudah digunakan oleh guru maupun siswa dan dapat mengurangi rasa jenuh yang dirasakan siswa SD/MI dalam pembelajaran berbasis e-learning. Biasanya guru membuat sebuah konten berupa materi-materi yang diajarkan kemudian menguploadnya di channel youtube pribadinya, kemudian mengirimkan link youtube tersebut melalui grup Whatsapp kelas (Alami, 2020).

Berdasarkan dari hasil kuesioner dan wawancara yang dilakukan secara online kepada 21 guru SD/MI di Jember, pada hasil penelitian (Gambar 3) sebanyak 34\% Guru SD/MI di Jember menganggap kuota internet merupakan penghambat paling besar bagi mereka dalam menggunakan dan mengakses media pembelajaran berbasis e-learning. Hal ini sesuai dengan penelitian Abidin et al., (2020) yang menyatakan bahwa paket internet yang tidak dimiliki oleh dosen dan mahasiswa menjadi hambatan yang paling sering terjadi sepanjang pelaksanaan proses pembelajaran online. Sebanyak 20\% guru SD/MI di Jember menganggap fasilitas/sarana prasarana menjadi penghambat dalam menggunakan dan mengakses media pembelajaran berbasis e-learning, banyak guru yang masih belum mempunyai sarana dan prasarana yang memadai atau sesuai dengan media pembelajaran berbasis e-learning yang mereka gunakan dan disamping itu guru juga mengalami kesulitan dalam menggunakan sarana media pembelajaran yang disediakan oleh pihak sekolah. Sebanyak 14\% jaringan internet menjadi penghambat guru SD/MI di Jember dalam menggunakan dan mengakses media pembelajaran berbasis e-learning, dalam proses pembelajaran berbasis $e$ learning jaringan yang tidak stabil menjadi salah satu faktor penghambat guru dalam menyampaikan materi atau informasi dan tugas yang dilakukan melalui media pembelajaran berbasis e-learning. Karena dalam hal ini jaringan internet yang baik sangat menentukan kelancaran pembelajaran yang dilangsungkan secara e-learning, sehingga jika jaringan internet tidak stabil akan menjadi penghambat untuk guru saat mengakses media pembelajaran berbasis $e$ learning (Sudrajat, 2020). Sebanyak 14\% skill dalam menggunakan media pembelajaran berbasis 
e-learning menjadi penghambat guru SD/MI di Jember dalam pembelajaran e-learning, hal ini sama dengan hasil penelitian Nopiyanto et al., (2020) yang menyebutkan sebanyak $80 \%$ guru saat menggunakan aplikasi tertentu yang digunakan untuk proses pembelajaran daring seringkali mengalami hambatan, 75,5\% guru mengalami hambatan dalam memakai media pembelajaran yang bermacam-macam variasinya. Kemudian sebanyak $9 \%$ waktu menjadi salah satu faktor penghambat guru SD/MI dalam menggunakan media pembelajaran berbasis e-learning, karena tidak jarang guru kesulitan untuk mengatur target alokasi waktu saat melakukan proses pembelajaran e-learning. Terakhir sebanyak $9 \%$ terdapat faktor lain yang menjadi penghambat bagi guru SD/MI di Jember saat menggunakan atau mengakses media pembelajaran berbasis e-learning di masa pandemi COVID-19 ini, misalnya seperti biaya, keadaan pandemi seperti ini membuat pembelajran hampir di seluruh SD/MI di Indonesia khususnya di Jember dilakukan secara online atau secara e-learning, sehingga guru harus mengeluarkan biaya yang lebih besar untuk membeli kuota internet dan fasilitas yang dapat menunjang pembelajaran secara $e$-learning tersebut.

Berdasarkan dari hasil kuesioner dan wawancara yang dilakukan secara online kepada 21 guru SD/MI di Jember, pada hasil penelitian (Gambar 4) 26\% dari 21 responden guru SD/MI memilih fitur $e$-learning menjadi pendukung dalam menggunakan media pembelajaran berbasis $e$ learning, hal ini dikarenakan fitur e-learning sangat membantu guru dalam melaksanakan pembelajaran berbasis e-learning. Adapun fitur yang dibutuhkan guru dalam pembelajaran $e$ learning antara lain mengirim materi dan tugas, mengupload materi dalam bentuk video, ujian, serta forum untuk berdiskusi. Kemudian $26 \%$ akses jaringan internet menjadi pendukung bagi guru $\mathrm{SD} / \mathrm{MI}$ dalam menggunakan media pembelajaran berbasis e-learning, hal ini dikarenakan salah satu cara untuk keberlangsungan pembelajaran di masa pandemi saat ini adalah dengan pembelajaran berbasis e-learning dimana pembelajaran ini membutuhkan jaringan internet yang memadai untuk mendukung proses pembelajaran. Pembelajaran berbasis e-learning bisa terlaksana dengan baik karena ada beberapa faktor pendukung antara lain yaitu handphone, pulsa, kuota, serta jaringan internet yang stabil dan baik (Purwanto, 2020). Selanjutnya, 18\% fasilitas/sarana prasarana menjadi pendukung bagi guru SD/MI dalam menggunakan media pembelajaran berbasis e-learning, fasilitas seperti smartphone ataupun laptop sangat penting guna menunjang berlangsungnya pembelajaran berbasis e-learning di masa pandemi saat ini. Smartphone menjadi salah satu faktor pendukung bagi siswa dan guru dalam melaksanakan pembelajaran berbasis e-learning saat ini, karena penggunaan Handphone dalam pembelajaran daring dapat meningkatkan hasil belajar siswa (Anggrawan, 2018). Kemudian 15\% skill menggunakan media pembelajaran menjadi pendukung bagi guru SD/MI dalam menggunakan media pembelajaran berbasis e-learning. Berdasarkan hasil wawancara pada guru SD/MI yang kami peroleh, skill menggunakan media pembelajaran berbasis e-learning selain menggunakan Whatsapp yaitu guru bisa menggunakan Quizizz dan Google Form sebagai media pembelajaran berbasis e-learning. Masih banyak guru yang mempunyai skill terbatas 
dalam menggunakan media pembelajaran berbasis e-learning. Motivasi dan pemikiran negatif tentang penggunaan teknologi dalam pembelajaran berbasis e-learning menjadi salah satu faktor yang menyebabkan guru minim skill dalam pembelajaran berbasis e-learning saat ini. Kemudian $15 \%$ kuota internet menjadi pendukung bagi guru SD/MI dalam menggunakan media pembelajaran berbasis $e$-learning, hal ini dikarenakan tanpa adanya kuota internet maka pembelajaran berbasis $e$ learning tidak akan dapat berlangsung. Oleh karena itu salah satu faktor yang mendukung berjalannya pembelajaran berbasis e-learning adalah kuota internet. Untuk menunjang berlangsungnya pembelajaran jarak jauh, Kemendikbud pun memberikan bantuan kuota bagi siswa, mahasiswa, guru, serta dosen.

\section{UCAPAN TERIMA KASIH (Optional)}

Atas terselesaikannya Karya Ilmiah ini, penulis mengucapkan banyak terimakasih kepada:

1. Dr. Imron Fauzi, M.Pd.I selaku dosen pengampu mata kuliah Etika Profesi Keguruan IAIN Jember yang telah memberikan arahan dan motivasi kepada penulis selama pembuatan Karya Ilmiah ini.

2. Guru SD/MI di Jember selaku responden yang telah menyempatkan waktunya selama penelitian yang dilakukan oleh penulis.

\section{KESIMPULAN DAN SARAN}

\section{Kesimpulan}

Berdasarkan hasil penelitian yang telah dilakukan dengan menggunakan metode deskriptif kualitatif melalui penyebaran kuesioner menggunakan Google Form dan wawancara secara online menggunakan Whatsapp yang telah dilakukan pada guru SD/MI di Jember sebagai responden. Saat pandemi COVID-19 membuat guru SD/MI di Jember melakukan pembelajaran berbasis e-learning. Media pembelajaran berbasis e-learning yang paling banyak digunakan adalah Whatsapp sebagai media utama pembelajaran berbasis e-learning. Kemudian sebagai media pendukungnya guru SD/MI juga menggunakan Google Classroom, Edmoodo, Zoom, Quizizz, dan media pembelajaran berbasis e-learning lainnya. Dalam menggunakan media pembelajaran berbasis e-learning yang menjadi hambatan paling besar adalah kuota internet, kemudian juga terdapat faktor penghambat yang lain seperti akses jaringan internet, fasilitas atau sarana prasarana, waktu, skill menggunakan media pembelajaran. Sedangkan faktor yang mendukung guru SD/MI dalam menggunakan media pembelajaran berbasis e-learning yaitu fitur-fitur e-learning, fasilitas atau sarana prasarana, kuota internet, skill menggunakan media pembelajaran.

\section{Saran}

Seorang guru hendaknya menggunakan media pembelajaran yang dapat menarik motivasi siswa dan mudah digunakan oleh guru maupun siswa serta tidak membutuhkan kuota internet maupun biaya 
yang besar agar semua siswa bisa aktif dalam mengikuti pembelajaran walaupun menggunakan media berbasis e-learning.

\section{DAFTAR PUSTAKA}

Abidin, Z. et al. (2020). PEMBELAJARAN ONLINE BERBASIS PROYEK SALAH SATU SOLUSI KEGIATAN BELAJAR MENGAJAR DI TENGAH PANDEMI COVID-19. Jurnal Ilmiah Profesi Pendidikan, 5(1), pp. 64-70.

Alami, Y. (2020). Media Pembelajaran Daring pada Masa Covid-19 Online Learning Media during the Coronavirus Disease. Tarbiyatu wa Ta'lim: Jurnal Pendidikan Agama Islam, 2(1), pp. 49-56.

Anggrawan, A. (2018). Comparative Analysis of Online E-Learning and Face to Face Learning: An Experimental Study. Third International Conference on Informatics and Computing, pp. $1-4$.

Anhusadar, La Ode. (2020). Persepsi Mahasiswa PIAUD Terhadap Kuliah Online di Masa Pandemi Covid-19.Kindergarten, 3(1), p. 45.

Astini, N. K. Suni. (2020). Pemanfaatan Teknologi Informasi dalam Pembelajaran Tingkat Sekolah Dasar pada Masa Pandemi Covid-19. Jurnal Lampuhyang, 11(2), pp. 13-25.

Dewi, N. Budiana. (2018). Media Pembelajaran Bahasa: Aplikasi Teori Belajar dan Strategi Pengoptimalan Pembelajaran. Malang: Universitas Brawijaya Press.

Fauzi, I. 2018. Etika Profesi Keguruan. Jember: IAIN Jember Press.

Maulah, S., Nurul, F. and R.Ummah, N. (2020). PERKULIAHAN DARING SEBAGAI SARANA PEMBELAJARAN SELAMA PANDEMI COVID-19. ALVEOLI: Jurnal Pendidikan Biologi, $1(2)$, pp. 50-61.

Nopiyanto, Y. E. et al. (2020). HAMBATAN GURU PENDIDIKAN JASMANI GENERASI 80-AN DALAM PEMBELAJARAN DARING DI TENGAH PANDEMI COVID-19. Jurnal Sporta Saintika, 5(2), pp. 139-148.

Purwanto, A. et al. (2020). Studi Eksploratif Dampak Pandemi COVID-19 Terhadap Proses Pembelajaran Online di Sekolah Dasar. EduPsyCouns : Journal of Education, Psychology and Counseling, 2(1), pp. 1-12.

Putrawangsa, dan Uswatun. (2018). INTEGRASI TEKNOLOGI DIGITAL DALAM PEMBELAJARAN DI ERA INDUSTRI 4.0. Jurnal Tatsqif UIN Mataram, 16(1), pp. 42-54.

Putri, R. Setyowati. et al. (2020). Impact of the COVID-19 Pandemic on Online Home Learning : An Explorative Study of Primary Schools in Indonesia. International Journal of Advanced Science and Technology, 29 (5), pp. 4809-4818.

Sadiman, Arief. S. (2008). Media Pendidikan. Jakarta: PT Raja Grafindo Persada.

Simanihuruk, et al. (2019). E-Learning Implementasi, Strategi, dan Inovasinya. Medan: Yayasan 
Kita Menulis.

Subandi. (2011). DESKRIPSI KUALITATIF SEBAGAI SATU METODE DALAM PENELITIAN PERTUNJUKAN. Harmonia, 11(2), pp. 173-179.

Sudrajat, J. (2020). KOMPETENSI GURU DI MASA PANDEMI COVID-19. Jurnal Riset Ekonomi dan Bisnis, 13 (1), pp. 100-110.

Winkel, dan S. Hastuti. (2010). Bimbingan dan Konseling di Institusi Pendidikan. Yogyakarta: Media Abadi. 